\title{
The Uses of the Past. Anastasius Grün's Political Ideas in the Field of Fiction
}

\author{
Marija Javor Briski
}

\section{DOI: 10.18355/XL.2015.08.03.31-40}

\begin{abstract}
In his epic poem Pfaff vom Kahlenberg, published 1850, Anastasius Grün uses an idiosyncratic reception of the German comical literature of the Late Medieval Period and a depiction of the historical ritual of enthronement of the Dukes of Carinthia to criticize the social situation of the restoration period and to present his politically liberal ideas in a more or less hidden way. The transfer of oppositional ideas into the fictive world of literature and into the historical sphere of ancient traditions grants him a distanced position to the current historical conditions of the time.

Key words

Anastasius Grün, Bakhtin, reception of medieval literature, Vormärz (pre-March) period, restoration period, enthronement of Carinthian Dukes
\end{abstract}

\section{Introduction}

Anastasius Grün alias Count Anton Alexander von Auersperg (1806-1876) published most of his works (cf. Santifaller, 1957: 36) in the Vormärz era/the restoration period - according to Manfred Engel (2011: 213), the latter expression is the most appropriate name for the period between 1815 and 1848, as it does not imply a specification of the conflicting literary movements of the period. Seeing the controversial role of Count Auersperg as poet, politician and feudal lord (cf. Kucher, 2011: 254), it is also most appropriate for him. The poet was born in Ljubljana and except for his education in Vienna and Graz and his countless travels - he spent most of his life at Thurn am Hart, in the family mansion, which the Auerspergs, the most important noble family in the former Carniola, owned for several centuries (Lozar Stamcar, 2004: 232). As the owner of a large estate, he faced several financial and political problems (Castle, 1909a). In contrast to his publicly declared liberalhumanistic points of view he treated his serfs arrogantly, inhumanely and without mercy (Birk, 2008: 3).

He learned to speak Slovenian in his childhood and formed friendship with Slovenians, yet his attitude towards the Slovenian people in general was ambivalent (Janko, 1998: 117). His role as a liberal author is thus to be separated from his role as a leading politician of the German community in Carniola (Janko, 1998: 118). Whereas his poetic translation of the folk poetry of Carniola (Volkslieder aus Krain) undisputedly deserves credit for the transmission of Slovene culture to the German cultural space (Janko, 1998: 122), he nevertheless donned a German Nationalistic (Deutschnational) attitude as a politician (Janko, 1998: 117). In the period of cultural struggles his attitude towards Slovenes even aggravated to such an extent that he referred to them as a product and image of reverse Darwinism (Birk, 2008: 3). Even though his "Vaterland des Herzens" (Motherland of the heart), as he wrote to his friend Bauernfeld on February $3^{\text {rd }} 1849$ (Castle, 1909a: XX; Birk, 2008: 3) was Germany, he used the Slovenian cultural-political heritage for the subject matter of his epic poem Pfaff vom Kahlenberg (The Priest of Kahlenberg) (Grün, 1909: 67-253). He outlined the work, which was also connected to his great artistic ambitions, as early as the 1830s (Castle, 1909b: 69-70, 75). The writing of his epic poem was somewhat delayed so that it was only published in 1850 (Castle, 1909b: 72). At first glance it seems as if it consisted of rather incompatible parts. The poem is introduced 
by Grün's dedication to his friend Nicolaus Lenau (85-89), followed by the foreplay (90-95) and the three main chapters: Nithart (96-143), Otto (144-200) and Wigand (201-353). The readers did not welcome the work enthusiastically, some critics were even extremely negative. Next to linguistic and poetic imperfections the criticism and a justified one at that - was aimed especially at the insufficient epic connection of individual parts (cf. Castle, 1909a: LXXXIV; Castle, 1909b: 73-74). However, the unity of the epic is not based on an internal necessity of the narrated events but rather on an idea that the poet intended to depict using various individual images (Castle, 1909b: 77). So, what is the "idea" of this work?

Anastasius Grün drew the attention of censorship to himself with his liberally formed, oppositionally critical lyrical and tendentious poem collections Spaziergänge eines Wiener Poeten (Promenades of a Vienna Poet) and Schutt (Rubbish) (Castle, 1909a: XXX, XXXII-XXXIV). Once his pseudonym was discovered, he had to promise Metternich to either leave the country or stop publishing (Castle, 1909a: LXVII). He chose for the latter, but though he remained in his homeland, his word of honour never kept him from continuing his literary triad in the remoteness of his family residence. However, he kept postponing the publication of the work, leaving it to ripen for over fifteen years, since the poem, as evident from Auersperg's statement, occasionally failed to comply with the demands of censorship (Castle, 1909b: 69). In the aforementioned letter to Bauernfeld, dated February $3^{\text {rd }}$ 1849 , the author - amongst other things - expresses his fears that the influence of the Vormärz circumstances that reigned the country was too great and the characteristics thereof are too obvious in his work (Castle, 1909b: 72). In opposition to this statement, Grün assured his friend Hammer as early 1837 that he had given up on the tendentiousness in the Pfaff vom Kahlenberg (Castle, 1909b: 70). Based on these contradicting statements I argue the point that the poet uses an idiosyncratic reception of late medieval fiction literature as well as a depiction of the enthronement of Carinthian Dukes to more or less covertly transmit his ideas, which were at the time regarded as revolutionary. The adaptation of literary works and an inclusion of historical elements into his epic thus serve as taking a stance on the socio-political circumstances of the time and represent a new design of his contemporary society (cf. Göttsche, 2011: 223). It is not my intention to depict the entire political programme expressed by the author in his work, but rather to use some illustrative excerpts in order to demonstrate to what extent he used medieval literature and depiction of historical custom as a messenger of his political ideas and to also show the strategies he used - consciously or not - to avoid the keen eye of the censorship.

As it is evident from the analysis of the epic, there are three main characters: the Austrian Duke Otto der Fröhliche (Otto the Merry, 1330-1339), who was a great art lover, and the legendary merrymakers Neithart Fuchs (spelled as "Nithart" in Grün's epic) and the Priest of Kahlenberg (cf. Jöst, 1986: 101; Rupprich, 1966: 301) whose identities have not been reliably explained by researchers (cf. Maschek, 1936: 33-46). Grün used various literary sources (cf. Castle, 1909b: 76): the farces of Neithart (Bobertag, 1885: 141-292), the work of Philipp Frankfurter, Geschicht des pfarrers vom Kalenberg, i.e. "The Story of the Priest from Kalenberg" (Bobertag, 1885: 3-86), the work of Johann Jacob Fugger (1668) Spiegel der Ehren des Höchstlöblichen Kayser= und Königlichen Erzhauses Oesterreich (The Mirror of Honour of the Most Honourable Imperial and Royal Dynasty of Austria) and others, which served him as sources of various individual excerpts and motives. He brought these various elements together in his poem after he had altered their form and added the spice of his own imagination (cf. Jöst, 1986: 110). The work Ehrenspiegel (Mirror of Honour), e.g. includes the funny tale of rolling skulls that are not a part of the Frankfurter compilation (cf. Maschek, 1936; 44-45), and the name of Wigand; as the 
otherwise anonymous priest of Kahlenberg is named in Grün's epic poem. There are some excerpts, e.g. the funny story of the violet (Bobertag, 1885: 153-162) and the tale of the cunning security measures taken during the visit of the Duke of Austria who wanted to see Neithart's beautiful spouse (Bobertag, 1886: 227-232), that were also taken from the literary tradition on Neithart.

\section{Analysis of Grün's adaptations of late medieval literary sources}

Nithart, a poet on the Viennese court of Duke Otto is looking for the first spring violet on the demand of his master. This tiny blossom is given greater importance in Grün's work than in the source material. The violet, known as harbinger of spring, bringing along blossoming and growth, should be a reminder to the ruler that he should take care for the well-being of his nation:

Drin [i.e. in the violet] steht: Wie ich [i.e. the spring] die Wälder und Hecken,

Sollst Du Dein Volk zum Blühen wecken,

Die Nebel scheuchen, die Eise sprengen,

Die sein erwachend Herz, noch engen,

Des Geistes Saaten reifen und hüten,

Mit Kränzen weckend neue Blüten;

So grüne, glänze maiengleich

Das Frühlingseigen Österreich! (Grün, 1909: 100)

(Is it written [i.e. in the violet]:

Just as I [i.e. the spring] do to the forests and the hedgerows,

thus must you bring your nation to blooming,

chase away the fog, break the ices

that still restrict the nation's waking heart,

let grow the seeds of the spirit and be their protector,

with wreaths awake new blossoms;

so let it turn green, let it shine as the May,

Austria, belonging to the realm of spring!)

These metaphorically expressed demands, which are to be fulfilled by the ruler, are obvious. Ruling is not primarily about taking care of the well-being of subjects, but rather about creating such inland conditions that enable a clear overview over previously blurred facts, thus a correct evaluation of the situation as well as a free development of spirit, which was becoming rigid under the influence of "the ice of censorship". Encouraging free thinking could also, as evident from the quote, form a base on which the country would prosper. It is evident that the initiative for the violet seeking quest - the flower which symbolizes freedom of thought and free speech (cf. Birk, 2008: 4) - was not taken by the people but rather by the ruler; he thereby becomes a personification of one of the ideals of an enlightened sovereign. The exclamation at the end of the quote transgresses the frame of fiction; the reader can associate it with the current situation in Austria at the time - one that was incongruent with such enlightened ideals (cf. Vocelka, 2002: 194-197).

Nithart takes his hat, which is decorated with a feathery crown in state colours (Grün, 1909: 100) and uses it to cover the violet, harbinger of spring, so that Duke Otto as "her" (i.e. the violet's) vassal may honour "her". In other words: the symbol of freedom is put away into a Kerkerverlies (Grün 1909: 102) - into a dark gaol. This is how Engelmar, who is of peasant origin, denotes the hat and thus draws attention to the deeper meaning of this prop - that thereby the freedom of subjects is in fact suppressed instead of properly protected. 
As Nithart goes to fetch his master, the peasants discover the violet just as in the source text, but here Engelmar's response acquires a revolutionary character: he is shocked to see the - as he perceives it - illegal intrusion of other classes into the peasant sphere, as this poses a threat to its existence:

\author{
Es ist ein keck Besitzergreifen, \\ Denn ungehemmt will Fürst und Ritter \\ Und Pfaff durch unser Eigen schweifen! \\ [...] \\ Heut ist ein Veilchen nur die Beute, \\ Doch morgen ist's der Fisch im See, \\ Das Wild im Forst, des Lämmleins Schnee, \\ der Dirne Kranz und Hof und Leute, \\ Der Hände Schaffen, des Herzens Glaube, \\ Ein Sterbekittel bleibt uns zum Modern! \\ Drum wehrt des Keiles Eindrang heute, \\ Daß euch die Zeit nicht alles raube, \\ Daß nicht, wenn später heim wir's fodern, \\ Die Kronen wanken, die Burgen lodern! \\ Des Ritters ist der Waffensaal, \\ des Fürsten der Pergamentenbund, \\ Des Pfaffen ist Brevier und Pokal, \\ Des freien Bauern der freie Grund! (Grün, 1909: 101-102).
}

(It is a cocky seizure,

unhindered do the earl and the knight

and the priest want to tread on our property!

[...]

Today only the violet falls prey to them,

but tomorrow it might be the fish in the lake,

the game in the forest, the white fluff of the lamb,

the wreath of the maiden and the homestead and the people,

the work of our hands, the faith of our hearts,

all that remains is a burial shroud for us to rot in!

Therefore protect yourselves today against the invasion of the wedge,

lest time robs you of everything,

that later, when we demand to take it back,

crowns won't sway nor castles burn!

The armoury is of the knight,

the parchment of the earl,

the breviary and the cup of the priest,

but free land belongs to the free peasant!)

These words ring with the demand of peasants for free land ownership, protest against the authorisations of the nobility and an uprising against serfdom, which still remained despite the Serfdom Patent (cf. Zöllner, 1990: 361-362).

The peasants seize the violet just like in the medieval funny story and one of them "ließ zurücke, / Was sich nicht singen und sagen lässt" (Grün, 1909: 102; i.e. "left behind, / what can be neither sung nor said out loud.") Should what was "left behind" (human excrements) instead of a symbol of the ruler's ideal (the violet) represent the real situation in the Vormärz era? The answer is up to the reader. 
At the end of the funny story about the violet, the narrator surpasses the fictitious level and - in a fateful prophecy - reminds us of the revolutionary stirrings of the time, when the epic was being written. Thus emerged a dialogization between the story and history (cf. Bachtin, 1979: 157, 169, 175, 331). On the one hand, the narrator's comment directs the interpretation of the humorous story, and on the other hand it remains vague enough, as specific time and place data are absent from the process of connecting the story with the historical endowments:

\author{
Der Kampf, der um ein Blümlein heute \\ Unblut'ge Wunden, Beulen geschlagen \\ Er schlägt um reichere, größre Beute \\ Wunden, die nicht zu heilen wagen; \\ Sie werden heim die Beute fodern, \\ Dann wanken Kronen, Burgen lodern! - \\ Das Lied doch greift nicht vor den Zeiten, \\ Es darf noch durch die Blumen schreiten. (Grün, 1909: 104)
}

(The fight for the flower which today caused superficial wounds and bumps, will one day be fought for a richer loot, with wounds that won't be healed; They will take that loot home, then crowns will sway and castles burn!But this poem does not run ahead of time, it may still walk through flowers.)

The stealing of the violet provokes Nithart's hatred of the peasants both in the original literary source and in the adaptation - a hatred expressed in the following peasant war (Grün, 1909: 104-136). We will take a look at one story from this chapter - "List gegen List" (i.e. Trick against trick; Grün, 1909: 116-123). Engelmar wants to take revenge for Nithart's vengeful actions, thus he encourages the Duke to get to know Nithart's beautiful spouse. As Nithart finds out about the imminent visit, he decides to take preventative measures in order to protect his marriage. He makes a false claim to his wife that the Duke lost his hearing during a tournament accident:

\author{
Drum schrei ins Ohr ihm, statt zu girren, \\ Laß auch sein Zürnen dich nicht irren, \\ Er hat die Art von allen Tauben, \\ Daß sie noch gut zu hören glauben. (Grün, 1909: 118) \\ (Therefore yell in his ear instead of whispering, \\ do not be confused by his anger, \\ he has the characteristic of all deaf people, \\ he believes he still can hear.)
}

Simultaneously, he tells his master that his wife is hard of hearing. Thus he prevents any potential whispering between the two that could grow into intimacy. Those familiar with the medieval source text are more or less familiar with this intention of Otto's supposed deafness, whereas Grün daringly takes it to another level. As Nithart's wife Friderune ponders the ruler's hearing impairment in her monologue, she does not only pity his wife, but also his country: 
1. O armes Reich, dein Fürst ist taub!

Weh, wer vertrauend, bittend wallt,

Sein scheu Geheimnis laut erschallt,

Dem Hof, der Stadt, dem Land zum Raub!

O armes Land, des Herrscher taub! (Grün, 1909: 119)

(O poor state, your earl is deaf!

Woe is he who comes to him with a request,

his shy secret will resound loudly

for the court, the town, the state to rob it from him!

Woe is the country whose ruler is deaf!)

On the one hand, the exclamation of this shocking realisation is in harmony with the fictitious level of the narration, and on the other hand, it signalises a contextual breakthrough and lures the reader into transferring the ruler's weaknesses and their consequences for the state and nation directly to the historical circumstances of the Vormärz era, when Ferdinand I ruled under Metternich's directive (cf. Zöllner, 1990: 352-355), a ruler who did not take into account the needs of his serfs. However, the complaint does not refer directly to the realistic historical circumstances and is deftly included in the fictitious narrative, therefore the censorship could not persecute the author.

Several other intrigues follow, yet chapter 1 ends in reconciliation, whereas in the source text the hatred between Neithart and the peasants remains even after Neithart's death. Grün's epic transforms the mythically stylized peasants' enemy of the medieval tradition, who was regularly engaged in preserving the class division system which the peasants loosened (cf. Strohschneider, 1988: 168), into their ally. In this way, the necessity of cooperation between peasants and the higher educated strata representing their interests is expressed, so that also peasants manage to realize their political right to take part in decision making (Grün, 1909: 141; cf. Castle, 1909a: LXIV).

Amongst other motives the poet took from the work Geschicht des pfarrers vom Kalenberg, let us touch upon the motive of the church flag. Grün took the artistic liberty of replacing the original flag with random black pants that the priest coincidentally threw over a pole.

Da schwebt am Schaft im Lichtportale,

Erkennbar jedem Augenstrahle,

Das Ungetüm paniergestaltig,

Aus schwarzem Tuche, doppelspaltig,

Und läßt die derbe Wahrheit lesen:

Der Pfaff ist ein zweibeinig Wesen!

Ein Grollen braust durchs Volk gewaltig:

„Seht, Meister, Euren Kranz von Rosen!

O seht des Pfarrers schwarze--,, ,Stille!“

Gebot des Richters strenger Wille,

Beschwichtigend das Zornestosen. (Grün, 1909: 226-227).

(There, floating in the light portal,

visible for each eye to see,

is a monster shaped like a flag,

made of black cloth, in two columns, 
showing the unrefined truth:

the priest is a two-legged creature!

A mighty thunder roars o'er the people:

"Behold, master, your rosary!

O look at the priest's black - -" "Silence!"

orders the strict judge's will,

calming down the roars of anger.)

Wigand responds to the outrage of his parishioners with laughter. $\mathrm{He}$ explains to them that the pigeon as the symbol of peace became a black crow, a dark mourning veil replaced the bright wreath and the light-coloured state flag is substituted by a black vulture from the coat-of-arms. The text interpretation imposes the comparison of those pants with the vulture from the coat-of-arms - an obvious allusion to the two-headed eagle of the Habsburgs. This association in Bakhtin's (Bachtin 1995, 70; cf. Braun, 2002: 10) sense degrades a high state symbol in a carnivalistic manner by equating it with the slacks of a "two-legged creature". The comical optics lessen the dark seriousness of the symbolism, which can be connected with the Vormärz era.

We could depict many other contact points and comparisons between individual narratives, which are based on the late medieval literature and the political circumstances of the Vormärz era, but for now the aforementioned examples shall suffice.

\section{Enthronement of Carinthian Dukes}

In the second part of Grün's epic poem there is mention of the enthronement of Carinthian Dukes (Grün, 1909: 181-182, 190-198). It is known that the enthronement ceremony, last performed in 1414 (Štih, 1999: 11), was based on a tradition dating back to the era of Carantanian Dukes; some elements of the ceremony are allegedly even of Indo-European descent (cf. Pleterski, 1997: 43-119). The ceremony proceeded roughly as follows: The new Duke approached the oldest male member of a family of "kosezi" (a class of ennobled commoners, free Slovene peasants) from Blažnja vas village (Blasendorf). This peasant was sitting on the Ducal Stone close to Krnski Grad castle (Karnburg), holding a mottled bull with one hand and a mottled mare with the other. Once the Duke's entourage guaranteed to the "kosez" (peasant) that the Duke was a just judge of free birth who would care for the welfare of the land and respect and protect the Christian faith, the peasant would accept the Duke as his equal. Only then could the Duke, clad in peasant garments, take over the Ducal Stone and was thereby symbolically invested with the power over the country. Only after the Ducal ceremony, which was in the Slovene language and included the Duke's solemn oath, would the Bishop of Gurk bless him during a holy mass in the Gospa Sveta church (Maria Saal), even though the new Duke had received the duchy of Carinthia from the sovereign already before the ceremony. The feudal version of the ceremony took place in the afternoon of the same day at the Ducal Throne at the Gosposvetsko polje field (Zollfeld), where the new Duke distributed feuds to local gentry. In the High and Late Middle Ages the ceremony was a symbol of cooperation between the earl and the people with the founding and enforcement of the ruler's rights, through time it developed into a merely formal ceremony. (Štih, 1999: 11-13) There are three medieval sources that report about the enthronement ceremony: an insertion in two manuscripts from the $14^{\text {th }}$ and $15^{\text {th }}$ century copies of the Schwabenspiegel - a collection of legal customs and uses; Österreichische Reimchronik (Ottakar of Geul's rhymed chronicle) and the Liber certarum historiarum (A Book of True Stories) of John of Viktring (cf. Zöllner, 1990: 84). Next to these sources and newer historical works, Anastasius Grün was probably also familiar with 
Herder's enthronement poem, published in the collection of national poems of the same author (Castle, 1909b: 76).

In his epic Pfaff vom Kahlenberg many various opinions on the importance and necessity of this ancient ritual are expressed. Whilst the old "kosez" defends the ceremony as a guarantor for the rights and freedom of the nation, the younger generation, growing up under a just and kind-hearted ruler, finds it obsolete (Grün, 1909: 181-183). There is a continuous echo of ironical remarks aimed at the old historically attested ritual, but the narrator - unlike before, when he mostly gives up a direct connection with the current history of the Vormärz era - estimates this ceremony as an ideal worthy of copying and warns of the necessity that a ruler receives his power from the people (Grün, 1909: 190).

\section{Conclusion}

As demonstrated, both the excerpts, which are based on the late medieval literature, as well as those that depict the enthronement of the Carinthian Dukes communicate politically liberal ideas. The transfer of oppositional ideas into the fictitious world of comical literature of the Late Middle Ages and into the historical sphere of ancient rituals enable a certain distance from the historical circumstances in which the author lived. The creating of this distance can be interpreted as a defensive measure against censorship. Oppositional ideas are also alleviated through ironization and dialogization, e.g. with the depiction of enthronement of Carinthian Dukes.

In contrast to this, Grün uses mostly indirect strategies for steering of the reception in order to re-establish a connection with the current issues and make his demands clear. An example of such a strategy is the usage of exclamations when commenting on the pathetically elevated fictitious events and simultaneously signalizing the necessity of the expressed statement. The statement, the importance of which is accentuated by the exclamation surpasses the fictitious frame as it encourages the recipient to establish connections with the historical events. Such a connection with the important issues of the Vormärz era can be established by an informed reader thanks to obvious analogies between fiction and "reality".

In opposition to the prevailing usage of hidden strategies as a means of spreading liberal ideas with the help of fiction there are also examples of obvious political manifestations, such as e.g. the narrator's open propaganda of the transfer of power to the ruler from the hands of the people.

Granted, Grün's epic Pfaff vom Kahlenberg does not actually meet the standards of a masterpiece that could compete with Goethe's Faust (cf. Scharmitzer, 1996: 196). Having said that, however, it did enable the author to express his politically liberal ideas in a period when censorship was persecuting liberal thoughts. Is it questionable whether the epic should be classified as member of a group of literary works that - in contrast with Lukács' perception of temporal sequence between reality and literature - really do want to change the world (cf. Virant, 2014: 130). Based on the author's position in the society of the time, his attitude to serfs and his expressed reservations regarding the revolution (cf. Kucher 2011), this epic poem can only be seen as a fictitious platform where he toys with his liberal ideas without having to face the consequences in reality. 


\section{References}

BACHTIN M. M. 1979. Die Ästhetik des Wortes. Frankfurt am Main: Suhrkamp. ISBN 3-518-10967-7

BACHTIN M. M. 1995. Rabelais und seine Welt. Volkskultur als Gegenkultur. Frankfurt am Main: Suhrkamp. ISBN 3-518-28787-7

BIRK M. 2008. Österreichisch-slowenischer Kulturtransfer am Beispiel von Anastasius Grün und France Prešeren. In: Modern Austrian Literature, Vol. 41, No. 2, pp. 1-18. ISSN 0026-7503

BOBERTAG F. (ed.) 1885. Narrenbuch. Berlin/Stuttgart: W. Spemann.

BRAUN K. 2002. Karneval? Karnevaleske! Zur volkskundlich-ethnologischen Erforschung karnevalesker Ereignisse. In: Zeitschrift für Volkskunde Vol. 98, No. 1, pp. 1-15. ISSN 0044-3700

CASTLE E. 1909a. Anton Alexander Graf Auersperg (Anastasius Grün). Sein Leben und Wirken. In: CASTLE E. (ed.) 1909. Anastasius Grüns Werke. Erster Teil: Politische Dichtungen. Berlin/Leipzig/Wien/Stuttgart: Verlagshaus Bong\&Co., pp. XI-CLXI

CASTLE, E. 1909b. Einleitung des Herausgebers. In: GRÜN A. 1909: Pfaff vom Kahlenberg. Ein ländliches Gedicht. In: CASTLE E. (ed.) 1909. Anastasius Grüns Werke. Vierter Teil: Epische Dichtungen. Berlin/Leipzig/Wien/Stuttgart: Verlagshaus Bong\&Co., pp. 67-83

ENGEL M. (2011). Vormärz, Frührealismus, Biedermeierzeit, Restaurationszeit? Komparatistische Konturierungsversuche für eine konturlose Epoche. In: Oxford German Studies, Vol. 40, No. 3, pp. 210-220. ISSN 0078-7191

FUGGER J. J. 1668. Spiegel der Ehren des Höchstlöblichen Kayser= und Königlichen Erzhauses Oesterreich. Nürnberg: Mich U. Joh. Frider. Endtere.

GÖTTSCHE D. 2011. Zeiterfahrung und literarische Gedächtnispolitik in Novellen der Restaurationsepoche (1815-1830). In: Oxford German Studies, Vol. 40, No. 3, pp. 221-239. ISSN 0078-7191

GRÜN A. 1909. Pfaff vom Kahlenberg. Ein ländliches Gedicht. In: CASTLE E. (ed.) 1909. Anastasius Grüns Werke. Vierter Teil: Epische Dichtungen. Berlin/Leipzig/Wien/Stuttgart: Verlagshaus Bong\&Co., pp. 67-253

JÖST E. 1986. Bauernfeind und Schelmenpfaff. Zwei Wiener Schwankhelden aus dem Spätmittelalter. In: Wiener Geschichtsblätter, Vol. 41, pp. 101-114. ISSN 00435317

KUCHER P.-H. 2011. Legitimität und „Trostlose Gegenwart ...“ Österreich um 1840 aus dem Blick von Anastasius Grün und Viktor von Andrian-Werburg. In: Oxford German Studies, Vol. 40, No. 3, pp. 253-269. ISSN 0078-7191

LOZAR ŠTAMCAR M. 2004. Zibelka in legenda z gradu Šrajbarski turn. In: Etnolog, Vol. 14, pp. 231-241 ISSN 0354-0316

MASCHEK H. 1936. Die Geschichte des Pfarrers vom Kahlenberg. Historische Grundlagen. Verfasser. Entstehungszeit. In: Zeitschrift für deutsches Altertum und deutsche Literatur, Vol. 73, pp. 33-46

PLETERSKI A. 1997. Die Kärntner Fürstensteine in der Struktur dreier Kultstätten. In: Huber A. (ed.). Der Kärntner Fürstenstein im europäischen Vergleich. Symposium Gmünd 1996. Seeboden: Axel Huber, pp. 43-119

RUPPRICH H. 1966. Zwei österreichische Schwankbücher. Die Geschichte des Pfarrers vom Kahlenberg. Neithart Fuchs. In: HASLINGER A. (ed.) 1966. Sprachkunst als Weltgestaltung. Festschrift für Herbert Seidler. Salzburg: Pustet, pp. 299-316

SANTIFALLER L. (ed.) 1957. Österreichisches biographisches Lexikon: 1815-1950. 1. (A - Glä). Wien: Verlag der österreichischen Akademie der Wissenschaften, Graz: Böhlau, pp. 35-36 
SCHARMITZER D. 1996. Anastasius Grün: Versuch einer Monographie. Leben und Werk eines Autors des 19. Jahrhunderts im Lichte neuer Quellen. Dissertation, Wien: Universiät Wien

STROHSCHNEIDER P. 1988. Schwank und Schwankzyklus, Weltordnung und Erzählordnung im „Pfaffen vom Kalenberg“ und im „Neithart Fuchs“. In: Grubmüller K. (ed.). Kleinere Erzählformen im Mittelalter. Paderborn/München/Wien/Zürich: F. Schönigh Verlag, pp 151-171. ISBN 3-506-78460-9

ŠTIH P. 1999. Ustoličevanje koroških vojvod: najstarejša upodobitev $1480=$ The Oldest Picture of the Enthronement of the Dukes of Carinthia = Die älteste Darstellung der Kärntner Herzogseinsetzung. Ljubljana: Slovenska knjiga, pp. 5-24. ISBN 961-210-146-9

VIRANT Š. 2014. Zrcalo življenja ali njegov vzor: o realizmu v 20. stoletju. In: Primerjalna književnost Vol. 37, No. 3, pp. 125-137. ISSN 0351-1189

VOCELKA K. 2002. Geschichte Österreichs. Kultur - Gesellschaft - Politik. München: Wilhelm Heyne Verlag. ISBN 978-3-453-21622-8

ZÖLLNER E. 1990. Geschichte Österreichs. München: Oldenbourg, Wien: Verlag für Geschichte und Politik. ISBN 3-486-46708-5, 3-7028-0304-1

Words: 4802

Characters: 29854 (16.59 standard pages)

Assoc. Prof. Marija Javor Briški, PhD.

Department of German, Dutch and Swedish

Faculty of Arts

University of Ljubljana

Aškerčeva 2

1000 Ljubljana

Slovenia

Marija.Javor-Briski@ff.uni-lj.si 